\title{
Communication
}

[Comunicação]

\section{Infestation rate of the mite Varroa destructor in commercial apiaries of the Vale do Paraíba and Serra da Mantiqueira, southeastern Brazil}

\author{
[Taxas de infestação do ácaro Varroa destructor em apiários comerciais do Vale \\ do Paraíba e da Serra da Mantiqueira, sudeste do Brasil] \\ F.A. Pinto $^{1}$, A. Puker $^{1}$, D. Message $e^{2}$, L.M.R.C. Barreto ${ }^{3}$ \\ ${ }^{1}$ Aluno de pós-graduação -Universidade Federal de Viçosa - Viçosa, MG \\ ${ }^{2}$ Universidade Federal Rural do Semiárido - Mossoró, RN \\ ${ }^{3}$ Universidade de Taubaté - Taubaté, SP
}

The commercial apiculture in Brazil is a sustainable activity of great potential. Besides of honey, the bees offer many products including pollen, propolis, royal jelly and wax, and also play an essential role in pollination. However, with the emergence and spread of the mite Varroa destructor Anderson and Trueman (Acari: Varroidae), apiculture has become almost impossible in some countries without applications of chemical products for pest control (e.g., Rosenkranz et al., 2010). More intensely in recent years, apiculture has decreased along with the number of beekeepers and feral colonies. The real causes of this decline are yet to be clarified, but there are those who attribute pollination issues to the impact of $V$. destructor (e.g., Pinto et al., 2011ab).

Mechanisms of natural selection interact with the dynamics of varroa infestation rate (IR). Three mechanisms are sufficient for control of the mite in colonies: $i$ ) mite reproduction restricted to the drone brood (Garrido and Rosenkranz, 2004), ii) grooming and hygienic behaviour (e.g., Pinto et al., 2012) and iii) "entombing" of drone pupae where highly infested drones, that are unable to open their cocoons, are neglected by workers and eventually die within their brood cells (e.g., Rath, 1992).

In Brazil, $V$. destructor apparently did not causes significant damage to apiculture since the IR of adult bees is generally below $3 \%$, discarding the need of treatment (De Jong and Gonçalves,
1998). The first reports of varroa in Brazil occurred in the 1970s with considerably high IRs. However, the Africanized honeybees (AHB) used in Brazilian apiculture become tolerant to the mite in a short time. Genetic aspects of the mite may have facilitated the short acquisition of tolerance in AHB. Evaluations of genetic profile in mites collected in the 1970s showed a predominance of haplotype $J$, the mitochondrial genotype considered with lower reproductive potential and less harmful (Garrido et al., 2003). Although, even with the entry and spread of haplotype $K$, considered more detrimental, there are no reports of colony losses by varroa in Brazil.

Environmental factors have an influence on IR of the mite in colonies. Variables such as temperature, humidity, nectar flow and pollen availability may indirectly influence the proportion of viable offspring of varroa (Rosenkranz et al., 2010). Honeybee colonies in regions with temperate climates, such as in southern Brazil, are more prone to higher IRs and seasonal variations can also affects the infestation dynamics. For example, when evaluating the IRs of varroa on AHB in the state of São Paulo, Pinto et al. (2011a) verified that IRs may also depend on season, reaching higher values during the winter due to feed scarcity and consequent impairment of the colony. Several studies related to IR of varroa have been conducted in order to evaluate the possible resistance of bees to this pest, and it was found

Recebido em 26 de setembro de 2013

Aceito em 23 de dezembro de 2014

E-mail: fabio_ufv@hotmail.com 
that a high population density of parasite may cause a drop in production of resources and even colony death (e.g., Rosenkranz et al., 2010). In this study, the IRs of the mite $V$. destructor were evaluated on AHB and its possible relationship with environmental temperature in municipalities known for beekeeping of the "Vale do Paraíba" and "Serra da Mantiqueira", in southeastern Brazil.

Sixteen municipalities where beekeeping activity is well established of the "Vale do Paraíba" and "Serra da Mantiqueira" regions (São Paulo, Brazil) were selected for sample collection. A typical lower commercial apiary (specialized in honey production with $\sim 20$ Langstroth colonies) was selected in each municipality. Apiaries were in general located within or in the edges of the Brazilian Atlantic Forest, a common practice for commercial apiculture in the region. In all sampled apiaries, the practice of selecting queens resistant to $V$. destructor or other parasites/pathogens was absent.

Samples were collected during the summer season (December 2008 to March 2009) from each municipality. Three healthy populated colonies containing feed (honey and pollen) were randomly selected in every apiary for the collection of samples, characterizing three replicates per apiary. Approximately 300 adult bees were sampled from the breeding area of each colony, totaling a sampling effort of 48 colonies. Bees were placed inside labeled plastic containers $(500 \mathrm{~mL})$ containing $150 \mathrm{~mL}$ of $70 \%$ ethanol for storage.

Plastic containers containing the bees were shaken for three minutes to release the parasites and subsequently the bees were placed on a white surface to facilitate viewing the mites (adapted from De Jong et al., 1982). Afterwards, the bodies of the bees were individually checked and any mites still adhered to them after flask agitation were removed. This procedure was repeated twice, after which the mites found were counted along with the number of bees per sample, and the IR (in \%) was calculated.

Generalized Linear Models (GLM) were used to verify the effect of different municipalities (explanatory variables) on the IRs of $V$. destructor (response variables). All GLM were submitted to residual analysis, so as to evaluate adequacy of error distribution. The Pearson coefficient was determined to measure the level of correlation between IR and monthly temperature.

Information on the abiotic factors, including data of environmental temperature $\left({ }^{\circ} \mathrm{C}\right)$, were obtained from the "Centro de Pesquisas Meteorológicas e Climáticas Aplicadas à Agricultura" (Universidade de Campinas, Campinas, São Paulo, Brazil). The distances between apiaries and meteorological stations in each apiary ranged from 500 to $5,000 \mathrm{~m}$.

The average IR measured was $3.0 \%$, varying from 0.0 to $5.5 \%$ (municipalities of Paraibuna and Lorena, respectively). Lorena was the municipality with the highest IR, followed by Tremembé (4.6\%), Bananal (4.5\%), São José dos Campos (4.5\%) and Pindamonhangaba (4.4\%) (Figure 1).

As for the potential relationship between IR of the mite in adult bees and environmental temperature, it was found that the correlation was positive $(\mathrm{R}=0.676, P<0.05$ ) (Figure 2 ). This means that municipalities where the highest IR values were found were also among those with the highest temperatures, ranging from 23.7 (Pindamonhangaba) to $25.2{ }^{\circ} \mathrm{C}$ (Bananal).

IR values ranging from 0.0 to $5.5 \%$ found in the "Vale do Paraíba" and "Serra da Mantiqueira" were similar to those found in Ribeirão Preto (São Paulo, Brazil) (De Jong and Gonçalves, 1998), which is $\sim 600 \mathrm{~km}$ from where this study was conducted. Here, the IRs of $V$. destructor that were found are considered too small to damage the colonies $(>10 \%)$, even if kept for several seasons (De Jong and Gonçalves, 1998). Bacha Júnior et al. (2009) found average IR values varying from 3.3 to $11.0 \%$ during summer in apiaries of the "Zona da Mata Mineira" (state of Minas Gerais, Brazil), a region that has climatic patterns similar to the region studied in this paper. 


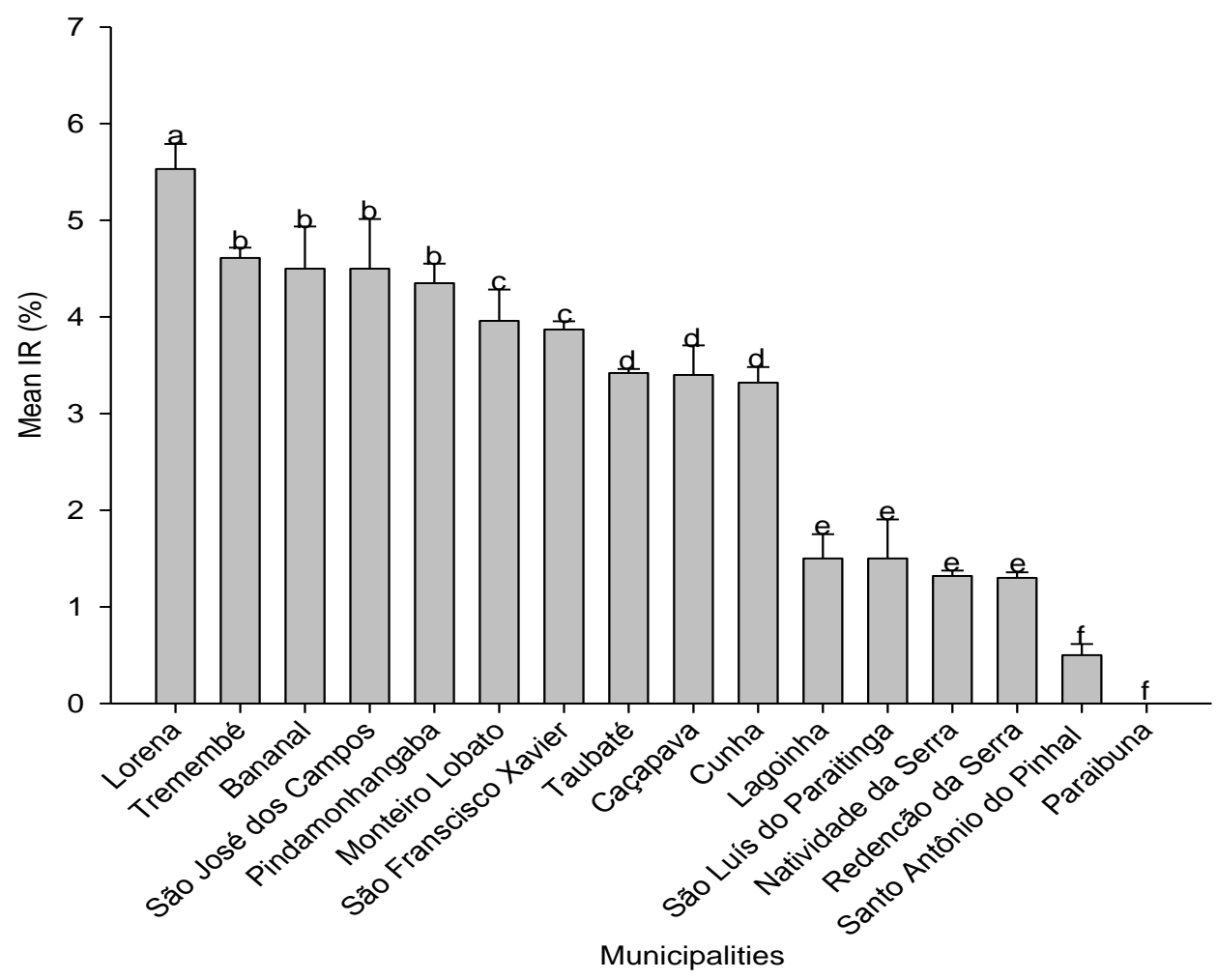

Figure 1. Mean infestation rate (IR, \%) of the mite Varroa destructor on adult bees in the different sampled municipalities of the "Vale do Paraíba" and "Serra da Mantiqueira" (São Paulo, Brazil). Bars on columns represent standard errors. Different letters above bars indicate significant difference between means $\left(\mathrm{F}_{(15.32)}=42.8062, P<0.01\right)$.

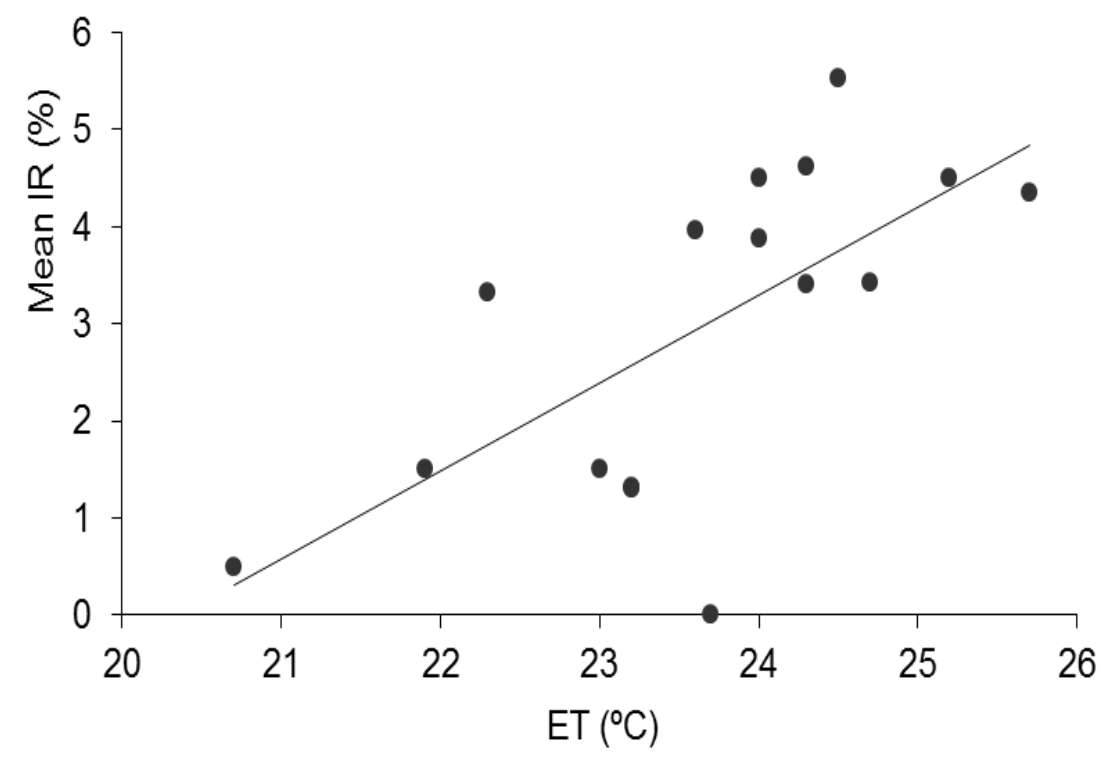

Figure 2. Correlation between the mean infestation rate (IR, \%) of the mite Varroa destructor and environmental temperature (ET, ${ }^{\circ} \mathrm{C}$; mean of summer 2008/2009) of the sampled municipalities of the "Vale do Paraíba" and "Serra da Mantiqueira" (São Paulo, Brazil). Pearson: $\mathrm{R}=0.676, P<0.05$. 
Even with a positive correlation, the overall range of variability of IR values $(5.5 \%)$ over the studied range of temperatures $\left(5^{\circ} \mathrm{C}\right)$ was narrow within the sampled municipalities (Figure 2). Hence, the abiotic factor environmental temperature should be viewed only as a secondary characteristic to explain the IR in AHB in the studied regions, because, for example, in the municipality of Paraibuna, which presented the highest average temperature (23.7 ${ }^{\circ} \mathrm{C}$ ) as compared to the others, presented IR of $0.0 \%$ (see Figure 1).

The low IR may be explained by a variety of factors that together give the "Vale do Paraíba" and "Serra da Mantiqueira" regions the tag of optimal places for apiculture. Among those factors that stand out are $(i)$ the bee race (Africanized) used widely in Brazilian apiculture, (ii) environmental temperature and (iii) haplotype of mites $(J)$ commonly found in Brazil, which is considered less harmful (Anderson and Trueman, 2000).

The sampling was performed during the summer and during this season the IRs of $V$. destructor in adult bees are generally lower when compared to those during the Brazilian dry winter (Pinto et al., 2011a). Variations in varroa IR were obtained among studied municipalities indicating that AHB tolerance to varroa can vary drastically even in a small region. A positive correlation of IR with environmental temperature was shown in summer. However, the infestation dynamics of the mite can vary differently among the seasons, when other effects, such as food availability, behavioral changes and interactions with other pathogens will interact in this relation.

In a study carried out to evaluate the seasonal effect of the IRs of varroa on AHB in apiaries of Juquitiba (São Paulo, Brazil), Pinto et al. (2011a) obtained average IRs that varied from 4.3 to $10.3 \%$ in adult bees for summer and winter, respectively. During the winter, in southern Brazil (Paraná) an IR of $17.1 \%$ was found in colonies of AHB (Pegoraro et al., 2000). This is probably explained by the decrease in temperature combined with the reduction of food resources which naturally weakens the colony, leaving it more prone to parasite invasion and infestation such as the mite (Pegoraro et al., 2000).

Other co-factors (e.g., relative humidity, flow of nectar and pollen availability) may affect IR of varroa. In this study, apiaries located in municipalities with higher altitudes $(1,000$ $1,500 \mathrm{~m})$ presented good conditions for developing of colonies like food resources during the period when the study was conducted due to their proximity with patches of the Brazilian Atlantic Forest. This fact can explain the lower results of IR in colder municipalities in this study, taking into consideration the correlation between environmental temperature and altitude. It is known that infestation of $V$. destructor in $A$. mellifera colonies is multifactorial; thus, a number of environmental and biological factors for both the parasite and host will determine the degree of infestation in each region.

The encountered IRs demonstrate that the tolerance of the AHB to the mite $V$. destructor in this region does not require the application of acaricides, substances that contaminate hive products, reducing their market value. However, given the variation in IRs between the colonies also shown in this study, it seems like that several factors like little environmental variations and co-factors related have a great impact in mite dynamics in colonies. Further studies like analysis on reproductive potential and evaluations in other seasons can provide a profile of varroa infestation dynamics in AHB, allowing monitoring and selection programs to prevent future problems with varrosis in Brazilian apiculture.

Keywords: abiotic factor, Africanized honeybees, Apidae, bee pathology, Varroidae

\section{RESUMO}

Nos últimos anos, grandes perdas de colônias de abelhas melíferas vêm sendo registradas em várias regiões do mundo. Contudo, os motivos desse acontecimento permanecem obscuros. O ácaro ectoparasita Varroa destructor Anderson e Trueman (Acari: Varroidae) pode ser um dos responsáveis por esse fato, principalmente como vetor de vírus. Neste estudo, avaliaram-se as taxas de infestação (TIs) do ácaro V. destructor em abelhas africanizadas Apis mellifera L. (Hymenoptera: Apidae) $e$ 
correlacionaram-se os dados com as médias de temperatura de 16 municípios das regiões do Vale do Paraíba e da Serra da Mantiqueira (São Paulo, Brasil), onde a apicultura comercial atua de maneira significativa. Em cada município, um apiário comercial foi selecionado para coleta de amostras de três colônias populosas (padrão Langstroth), totalizando 48 colônias amostradas. Aproximadamente 300 abelhas adultas localizadas na área de cria foram coletadas em cada colônia. As TIs variaram de 0.0 a $5.5 \%$, níveis considerados baixos para causar danos significativos às colônias. As TIs mais baixas foram encontradas em municípios com clima mais ameno durante a estação avaliada (verão). Adicionalmente, cofatores como variações na disponibilidade de alimento entre os municípios e a variabilidade genética das abelhas podem interagir na interação entre parasita e hospedeiro. A variação nas TIs entre os municípios indica que, mesmo presente, a tolerância das abelhas africanizadas ao varroa pode variar drasticamente em uma pequena região, devido à dinâmica multifatorial de infestação do ácaro.

Palavras-chave: abelhas africanizadas, Apidae, fatores abióticos, patologia apícola, Varroidae

\section{ACKNOWLEDGMENTS}

We thank the "Centro de Estudos Apícolas" at the "Universidade de Taubaté" (Taubaté, São Paulo, Brazil) for their support to this study, and the beekeepers that provided the bee samples.

\section{REFERENCES}

ANDERSON, D.L.; TRUEMAN, J.W.H. Varroa jacobsoni (Acari: Varroidae) is more than one species. Exp. Appl. Acarol., v.24, p.165-189, 2000.

BACHA JÚNIOR, G.L.; FELIPE-SILVA, A.S.; PEREIRA, P.L.L. Taxa de infestação por ácaro Varroa destructor em apiários sob georreferenciamento. Arq. Bras. Med. Vet. Zootec., v.61, p.1471-1473, 2009.

DE JONG, D.; GONÇALVES, L.S. The Africanized bees of Brazil have become tolerant to Varroa. Apiacta, v.33, p.67-70, 1998.

DE JONG, D.; ROMA, D.D.; GONÇALVES, L.S.A comparative analysis of shaking solutions for the detection of Varroa jacobsoni on adult honeybees. Apidologie, v.13, p.297-306, 1982.

GARRIDO, C.; ROSENKRANZ, P. Volatiles of the honey bee larva initiate oogenesis in the parasitic mite Varroa destructor. Chemoecology, v.14, p.193-197, 2004.

GARRIDO, C.; ROSENKRANZ, P.; PAXTON, R.J.; GONÇALVES, L.S. Temporal changes in Varroa destructor fertility and haplotype in Brazil. Apidologie, v.34, p.535-541, 2003.
PEGORARO, A.; MARQUES, E.M.; NETO, A.C; COSTA, E.C. Infestação natural de Varroa jacobsoni em Apis mellifera scutellata (Hymenoptera: Apidae). Arch. Vet. Sci., v.5, p.89-93, 2000.

PINTO, F.A.; PUKER, A.; BARRETO, L.M.R.C.; MESSAGE, D. The ectoparasite mite Varroa destructor Anderson and Trueman in southeastern Brazil apiaries: effects of the hygienic behavior of Africanized honey bees on infestation rates. Arq. Bras. Med. Vet. Zootec., v.64, p.1194-1199, 2012.

PINTO, F.A.; PUKER, A.; MESSAGE, D.; BARRETO, L.M.R.C. Varroa destructor in Juquitiba, Vale do Ribeira, southeastern Brazil: seasonal effects on the infestation rate of ectoparasite mites on honeybees. Sociobiology, v.57, p.511-518, 2011a.

PINTO, F.A.; SOUZA, G.K.; SANCHES, M.A.; SERRÃO, J.E. Parasitic effects of Varroa destructor (Acari: Varroidae) on hypopharyngeal glands of Africanized Apis mellifera (Hymenoptera: Apidae). Sociobiology, v.59, p.769-778, 2011b.

RATH, W. The key to varroa - the drones of Apis cerana and their cell caps. Am. Bee J., v.132, p.329-33, 1992.

ROSENKRANZ, P.; AUMEIER, P.; ZIEGELMANN, B. Biology and control of Varroa destructor. J. Invertebr. Pathol., v.103, p.96-119, 2010. 